\title{
Comparative Study on existing livestock production scenario in some selected areas of Sylhet region in Bangladesh
}

\author{
R. Khatun ${ }^{1}$, S Ahmed ${ }^{1}$ M.A. Hasan ${ }^{1}$, A.S.M. Ashab Uddin ${ }^{1}$, , M.J. Uddin ${ }^{2}$ and M.A. Alam ${ }^{3}$ \\ ${ }^{1}$ Training Planning and Technology Testing Division, Bangladesh Livestock Research Institute,Savar \\ Dhaka-1341, ${ }^{2}$ Department of Animal Science, Sylhet Agricultural University, Tilagar, Sylhet and \\ ${ }^{3}$ System Research Division, Bangladesh Livestock Research Institute, Savar Dhaka-1341.
}

\begin{abstract}
The study was designed to know the existing stocks under subsistence farming conditions to a specific area in Sylhet districts. Keeping this mind Bangladesh Livestock Research Institute initiated a baseline survey, awareness build-up through training programme and proper technical advisory services during July 2015 to June 2016 in Jaintapur and Balaganj upazilas under Sylhet district. For doing this, a total 200 respondents from two upazilas were randomly selected and interviewed face to face interview of every family in the village through pre-tested questionnaire for collection of information. A focus group discussion was also carried out to supplement the surveyed covering to assess the household asset possession, existing livestock production potentiality, available feed resources and disease prevalence situation as well as to find out the constraints prevailed at farmers level. After completing the base line survey, one hundred beneficiaries were selected randomly from two upazillas (50 from each upazilla) and were given training and demonstration of farm management activities and side by side proper technical advisory services also for creating awareness. The findings of baseline survey information indicated irrespective of the land, manpower, livestock resource and other input that are always being considered as social and economical up-liftman indicator for and specific area, the studied area is not exceptional. Any technology when introduce for specific area for specific purpose most of cases found remarkable improvement. So the scope and opportunity that is prevail in the studied area, being nourished through respective technological intervention for livestock development could be achieved. In this regard especially for livestock development, BLRI developed suitable technological intervention and awareness build-up programme is needed to a large area in different parts of the country to increase the overall existing livestock productivity to a great extent.
\end{abstract}

(Key words: Baseline survey, livestock community, awareness build-up, Sylhet)

\section{Introduction}

Farming system research is an approach to agricultural research that views the whole farm as a system. It focuses on selecting targeted areas and farmer's problems as well as identifies the opportunities. Moreover, it gives emphasis on designing and executing on-farm research and evaluating the intervention result. If technologies are not developed appropriately at the farmer's level, no other programs will boost up any significant effects. So, a new paradigm that might incorporate both people centered and technological solution to the specific needs of poor livestock keepers. It is generally agreed that new practices and technologies introduced through farming systems research enhanced agricultural production. It is evident that livestock enable saving, provide security, allow resource-poor households to accumulate assets, and help finance planned expenditures as well as those that are unplanned (i.e. illness). Livestock production as insurance policies and bank accounts in many parts of

*Corresponding author: rkbaby96@yahoo.com

Bang. J. Livs. Res. Special Vol. 21-25, 2018: P. 56-64, ISSN 1022-3851 
the developing world (Pell et al., 2010).The livestock subsector, as an integral component of the agricultural sector, plays a very significant role at the national and household level economy contributing $2.79 \%$ to the GDP and providing employment to a large proportion of the population that relies on livestock for livelihood (BBS, 2017). In order to increase livestock's contribution to the livelihoods of developing communities requires improved understanding of livestock's multiple and complex roles. The contribution of food from animal origin to the nutritional status of the world population is well documented (Ndlovu, 2010). Tembo et al., 2009 conducted a research work on Zambia named "Livelihood Activities and the Role of Livestock in Smallholder Farming Communities of Southern Zambia". They applied in-depth interview and focus group discussion (FGD) and observed that livestock sector contributed at about $52.8 \%$ of the livelihood of that country. Livestock at the hilly and haor area of Sylhet region is undoubtly a promising treasure of Bangladesh but day to day is going to be extinct because of lack of problem based adaptation of new technology and systematic farming system.

It is evident that a number of actors or institutions like GO, NGO and Donor agencies working with the support is usually withdrawn, it becomes useless. Remittance is the key element of the economy of these regions so, agricultural production contributes little in comparison to other districts of Bangladesh. Farmers usually use livestock as a draft power for land preparation as well as household consumption. At Sylhet area primary data was collected from field visit through a team focused on the existing available livestock resources and their problem and prospects and secondary collected from respective ULO office of the studied area. During data collection, following limitations were found that hindered the total livestock production compare to other district area (Statistical year book 2017) -

- Lack of awareness of farmer's to adopt technologies and systematic farming system

- Unavailability of feeds, fodder and pasture land

- Unplanned breeding

- Highly acidic soil and rapid climate change

- Low level of production potential

This project was planned to assess the socio economic status as well as existing production scenario under subsistence farming conditions as well as to identify what type of technologies required uplifting/improving the production status. Technological interventions are regarded as obligatory to improve productivity as well as livelihood. In this connection previously a project named 'Study on Model livestock Community Development Programme' was implemented in selected areas of Bangladesh for a period of three years through BLRI initiatives and had got a positive response to technological and health management intervention at farmers condition. Before introducing any validated technology to respective purposes, a comprehensive base line survey must be needed. Keeping these view in mind, socio-economic status along with identifying constraints and potentialities to survey the two selected area (Balaganj, Jaintapur) farmers in Sylhet region of Bangladesh. Considering it, this research work was undertaken to identify the existing livestock species along with level of 
productivity feed resources diseases pattern farming practices and to find out the constraints to and opportunities of livestock production in selected areas.

\section{Materials and Methods}

\section{Quantitative data analysis on different farm enterprises through baseline survey}

A baseline survey was carried out in different parts of the selected areas (two Upazila namely Balaganj and Jaintapur considering the hilly and haor area of Sylhet region) with a structured questionnaire. The questionnaire was prepared focusing the following parameter.

1. Farmer's asset possession and their personal information

2. Livestock and poultry inventory

3. Rearing system of livestock and poultry

4. Production system of livestock and poultry

5. Feeds and feeding of livestock and poultry

6. Crop cultivation pattern
7. Disease and health information

8. Socio-economic condition of the farmers

The selected areas and farmers were considered on the basis of their traditional crop production combined with livestock and poultry production system. Data was collected through face to face interview of 100 family head from each village aggregate total 200 family head in the selected village. A focus group discussion was also carried out to supplement the survey data Collected data were analyzed in accordance with the objectives considering Mean, standard deviation and percentage to illustrate the results.

\section{Features of the selected villages}

Different villages of Balaganj and Jaintapur Upazila of Sylhet district were selected purposively for the study based on concentration of livestock farming. Secondary data and information from different sources of both Government and non-Govt. organizations in the form of documents, report etc having relevance with this study were also consulted. The short description of two Upazila is shown in Table-1.

Table 1. The profiles of the study areas

\begin{tabular}{|c|c|c|c|c|}
\hline Upazila Name & Total area & Population & $\begin{array}{c}\text { Livestock } \\
\text { Population }\left(10^{3}\right)\end{array}$ & Consists \\
\hline $\begin{array}{l}\text { Balaganj } \\
\text { (River/ Haor area) }\end{array}$ & $\begin{array}{l}389.51 \text { sq. km } \\
\text { Density } 658 / \mathrm{skm}\end{array}$ & $2,56,239$ & 181.95 & $\begin{array}{l}14 \text { Union parishads, } \\
241 \text { Mouzas and } \\
471 \text { Villages }\end{array}$ \\
\hline $\begin{array}{l}\text { Jaintapur } \\
\text { (Hilly area) }\end{array}$ & $\begin{array}{l}258.68 \text { sq. km. } \\
\text { Density } 470 / \text { skm }\end{array}$ & $1,21,458$ & 176.03 & $\begin{array}{l}5 \text { Union parishads, } \\
160 \text { Mouzas and } \\
177 \text { Villages }\end{array}$ \\
\hline
\end{tabular}

(Source: DLS, 2015) 


\section{Profile of Balaganj upazila}

Balaganj Upazila ranks 4th in area measuring scale out of 12 Upazilas of Sylhet district. It has 42419 units of household and total area is $389.51 \mathrm{sq}$. $\mathrm{km}$. It is located between $24^{\circ} 36^{\prime}$ and $24^{\circ} 47^{\prime}$ north latitudes and between $91^{\circ} 38^{\prime}$ and $91^{\circ} 56^{\prime}$ east longitudes. Kushiara River passes through the Upazila. It is bounded on the north by Sylhet Sadar and Bishwanath Upazilas, on the east by Fenchuganj Upazila, on the south by Maulvibazar Sadar Upazila and Rajnagar Upazila of Maulvibazar zila and on the west by Jagannathpur Upazila of Sunamganj zila and Nabiganj Upazila of Habiganj zila. Balaganj came into existence on 10 January 1922 as Thana. It is learnt that in the past the Zamindar of Barachar built a temple of God Madan Mahan here. A trading centre means 'ganj' was developed in and around the temple, which specially became popular to Hindu ladies for high quality of Bangles locally known as Bala. The Upazila might has got its name Balaganj from the combination of these two wards Bala and ganj. The Upazila consists of 14 union parishads, 241 mouzas and 471 villages. Balaganj Upazila has a population 2,56,239 of which $50.97 \%$ are male, $49.03 \%$ are female, of which Muslim 90.04\%, Hindu $9.89 \%$, Christian and others $0.07 \%$. About $47.8 \%$ people were literate for both sexes, and in the case of male, it was $50 \%$ and for female it was $47.2 \%$. The density of population was 658 per square kilometer.

\section{Profile of Jaintapur upazila}

Jaintapur Upazila ranks 8th in area measuring scale out of 12 Upazilas of Sylhet district. It has 21293 units of household along with total area of 258.68 sq. km. including 18.51 sq. $\mathrm{km}$. forest area. It is located between $24^{\circ} 59^{\prime}$ and $25^{\circ} 11^{\prime}$ north latitudes and between $92^{\circ} 03^{\prime}$ and $92^{\circ} 14^{\prime}$ east longitudes. The Upazila is bounded on the north by India, on the east and south by Kanaighat Upazila and on the west by Gowainghat Upazila. Jaintapur came into existence in 1903 as Thana. Nothing is definitely known about the origin of the Upazila name. It is learnt that there lived a famous king named Gohak in the old Sreehatta region. He had three sons named Ludak, Gurak and Jaintak. After his death, the kingdom was divided among three sons and they became kings of three separate kingdoms. The part of the kingdom ruled by Jaintak was named as Jainta after his name. It is believed that the Upazila might has derived its name from the name of that kingdom. The Upazila consists of 5 Union parishads, 160 Mouzas and 177 Villages. Jaintapur Upazila has a population $1,21,458$ of which $52.08 \%$ are male, $47.92 \%$ are female, of which $81.2 \%$ Muslim, 15.9\% Hindu, 04\% Christian and $0.9 \%$ is others. About $35.1 \%$ people were literate for both sexes, and in the case of male it was $39.5 \%$ and for female it was $30.3 \%$. The density of population was 470 per square kilometer.

\section{Statistical analysis}

The collected data and information from field surveys, interviews, discussions and communication were scrutinized, classified, edited and coded. For analyzing the data, descriptive statistics such as sum, average and percentages were used to achieve the objectives and to get the meaningful results. The t-statistics was applied to test the significance of relevant parameters in between two surveyed areas. 


\section{Results and Discussion}

\section{Farm and family information}

The personal profiles of the surveyed farmers are summarized in Table 2. The results of survey showed that the average family size was found larger for Jaintapur (7.53) and smaller for Balaganj (6.85) which was the higher than the national average of 4.53 (HIES, 2010), but opposite situation was found in respect to earning member of the family. Livestock based community farming is a skill based enterprise and it requires some education to manage the enterprise in a well-tuned manner. But the results of survey showed that the one third of the total population of the village were illiterate, however most of the farmers (36.25\%) were having primary education in Jaintapur and $33.75 \%$ in Balaganj. But the education level did not differ significantly among the location. On the basis of age, each family had almost equal proportion of male and female members.

The dwelling houses along with homestead land differed significantly $(\mathrm{P}<0.01)$ and cultivable land, pond, and vegetable land also differed significantly $(\mathrm{P}<0.05)$, but other remaining land categories did not differ among locations. For the reasons some hills or ununiformed areas are present in Jaintapur and some water bodies at the haor area or Balaganj of Sylhet region. The land size of Jaintapur and Balaganj were 185.57 and 223.73 decimal per farm respectively. The farmers of Jaintapur and Balaganj owned, on average, $52.09,110.27,2.31,2.64,0.51$, $6.82,10.15$ and $18.67,188.72,6.00,5.83$, $0.42,4.00,0.55$ decimals of land including homestead, cultivable land, pond, vegetable land, livestock farm, fodder and fellow land respectively in Sylhet region (Table 3). The surveyed result indicated that livestock farming was prevailed narrow and some land was not used for cultivation. The annual

Table 2. Farm and family information of the community farmers

\begin{tabular}{llllc}
\hline Parameters & \multicolumn{2}{c}{ Location } & P-value & \multicolumn{2}{c}{$\begin{array}{c}\text { Significance } \\
\text { level }\end{array}$} \\
\cline { 2 - 3 } & Jaintapur & Balaganj & & NS \\
Family size (no./farmer) & $7.53 \pm 0.39$ & $6.85 \pm 0.38$ & 0.20 & NS \\
Earning member (no./farmer) & $1.73 \pm 1.15$ & $2.89 \pm 0.87$ & 0.43 & NS \\
Age (Years) & $42.95 \pm 1.45$ & $43.21 \pm 1.41$ & 0.89 & NS \\
Male (<18yrs) & $1.66 \pm 0.14$ & $1.37 \pm 0.13$ & 0.13 & NS \\
Female (<18yrs) & $1.59 \pm 0.13$ & $1.41 \pm 0.12$ & 0.31 & NS \\
Male (>18yrs) & $2.25 \pm 0.17$ & $2.02 \pm 0.16$ & 0.34 & NS \\
Female (>18yrs) & $2.09 \pm 0.18$ & $2.08 \pm 0.17$ & 0.98 & \\
Education (\%) & & & & NS \\
Illiterate & $22.5 \pm 4.60$ & $20.0 \pm 4.60$ & 0.70 & NS \\
Can sign only & $11.25 \pm 3.90$ & $17.5 \pm 3.90$ & 0.26 & NS \\
Up to Primary & $36.25 \pm 5.30$ & $33.75 \pm 5.30$ & 0.74 & NS \\
Upto high school & $20.0 \pm 4.50$ & $20.0 \pm 4.50$ & 1.00 & NS \\
Up to SSC & $10.00 \pm 2.60$ & $5.00 \pm 2.60$ & 0.23 & NS \\
Up to HSC & $8.00 \pm 0.80$ & $12.5 \pm 0.80$ & 0.31 & \\
\hline
\end{tabular}

$\mathrm{NS}=$ Non significant $(\mathrm{P}>0.05)$ 
income per farm per year was found higher $\left(\right.$ Tk115.65 $\left.\times 10^{-3}\right)$ in Balaganj then Jaintapur $\left(T k 114.31 \times 10^{-3}\right)$ but that did not found significantly difference $(\mathrm{P}>0.05)$. occupation found and agriculture holds first position of selected farming community. About 45\% farmers were engaged with livestock farming but they did not take care

Table 3. Land distribution Pattern of the community farmers

\begin{tabular}{lllcc}
\hline Parameter & \multicolumn{2}{c}{ Location } & P-value & \multirow{2}{*}{ Sig. level } \\
\cline { 2 - 3 } & Jaintapur & Balaganj & & \\
\hline Land distribution & & & & \\
$\quad$ Land size (dcm./Farn) & $185.57 \pm 33.39$ & $223.73 \pm 32.79$ & 0.41 & NS \\
$\quad$ Homestead & $52.09 \pm 6.31$ & $18.67 \pm 6.23$ & 0.0003 & $* *$ \\
$\quad$ Cultivable land & $110.27 \pm 27.69$ & $188.72 \pm 27.34$ & 0.03 & $*$ \\
$\quad$ Pond & $2.31 \pm 1.20$ & $6.00 \pm 1.20$ & 0.04 & $*$ \\
$\quad$ Vegetable land & $2.64 \pm 1.62$ & $5.83 \pm 1.60$ & 0.16 & $*$ \\
$\quad$ Livestock farm & $0.51 \pm 0.31$ & $0.42 \pm 0.31$ & 0.84 & NS \\
$\quad$ Fodder & $6.82 \pm 3.76$ & $4.00 \pm 1.92$ & 0.20 & NS \\
\hline Fallow & $10.15 \pm 6.04$ & $0.55 \pm 5.96$ & 0.26 & NS \\
Annual income (thousand taka) & $114.31 \pm 8.90$ & $115.65 \pm 2.90$ & 0.91 & NS \\
\hline
\end{tabular}

** Significant at $1 \%$ level $(\mathrm{P}<0.01)$, Significant at $5 \%$ level $(\mathrm{P}<0.05), \mathrm{NS}=$ Non significant $(\mathrm{P}>0.05)$

\section{Occupational scenario}

The Occupation of the surveyed farmers are shown in Table-4. The Agri-based occupation was found higher in Balaganj (91.02) than in Jaintapur (77.32) and it also differed significantly $(\mathrm{P}<0.01)$ because most of the land area is covered by Haor area and people are mostly engaged fishing business in Balaganj rather than Jaintapur but other occupation did not differ significantly between the two locations. Livestock dominated farming systems stands second sincerely due to low literacy rate, awareness lacking and also found weak communication regarding road, extension support service observed during survey time.

\section{Livestock and poultry in possession}

The existing livestock population and their management in study area are shows in Table-5. It revealed that number of livestock species in each farm family was very small and most of the livestock species were indigenous. The surveyed result showed that

Table 4. Distribution Pattern of Occupation at the community farmers

\begin{tabular}{lcccc}
\hline \multirow{2}{*}{ Occupation (\%) } & \multicolumn{2}{c}{ Location } & P-value & \multirow{2}{*}{ Sig. level } \\
\cline { 2 - 3 } & Jaintapur & Balaganj & & \\
\hline Agriculture & $77.32 \pm 4.18$ & $91.02 \pm 4.07$ & 0.01 & $* *$ \\
Labor & $4.05 \pm 2.20$ & $3.85 \pm 1.20$ & 0.94 & NS \\
Employment & $2.70 \pm 1.60$ & $1.30 \pm 1.51$ & 0.53 & NS \\
Business & $11.25 \pm 2.42$ & $15.12 \pm 1.13$ & 0.61 & NS \\
Livestock & $43.75 \pm 2.20$ & $45.00 \pm 2.32$ & 0.51 & NS \\
Fishery & $2.52 \pm 2.20$ & $3.50 \pm 1.20$ & 0.71 & NS \\
\hline
\end{tabular}

** Significant at $1 \%$ level $(\mathrm{P}<0.01), \mathrm{NS}=$ Non significant $(\mathrm{P}>0.05)$ 
most of the farmers in study areas reared more native cattle and poultry (either chicken or duck or both) then other species. But some peoples of both locations reared crossbred cattle. The population of crossbred cattle and chicken in study area differed significantly $(\mathrm{P}<0.05)$. On the other hand, the farmers of native cattle significantly differed $(\mathrm{P}<0.05)$, but the farmers of crossbred cattle and duck differed highly significantly in both location $(\mathrm{P}<0.01)$. It was also revealed that farmer's experience of livestock differed significantly $(\mathrm{P}<0.05)$ as well as tethering system, extensive, semi-extensive system of livestock rearing differed significantly $(\mathrm{P}<0.01)$. Usually, livestock and poultry species were solely under the custody of the female member of each household and male member was not too much interested about the income from that sources. It was revealed that livestock dominated farming systems were the common scenario of resource-constrained farming community.

\section{Productivity of existing livestock and poultry}

The productivity of animal and birds was analyzed for the in study areas which are shown in Table-6. The productive and reproductive performance of animals and birds did not differ $(\mathrm{P}>0.05)$ among the locations. The result revealed that the production performance of livestock species were poor due to lack of awareness and

Table 5. Livestock and Poultry management system in the community farms

\begin{tabular}{lllll}
\hline \multicolumn{1}{c}{ Parameters } & \multicolumn{2}{c}{ Location } & \multirow{2}{*}{ P-value Sig. level } \\
\cline { 2 - 3 } & Jaintapur & Balaganj & & \\
\hline Livestock population (no/house) & & & & \\
Native cattle & $3.31 \pm 0.28$ & $4.09 \pm 0.37$ & 0.09 & NS \\
Crossbred cattle & $0.12 \pm 0.03$ & $0.06 \pm 0.05$ & 0.05 & $*$ \\
Buffalo & $0.16 \pm 0.08$ & $0.16 \pm 0.10$ & 0.99 & $\mathrm{NS}$ \\
Goat & $1.57 \pm 0.27$ & $1.32 \pm 0.57$ & 0.57 & $\mathrm{NS}$ \\
Sheep & $0.09 \pm 0.06$ & $0.05 \pm 0.08$ & 0.66 & $\mathrm{NS}$ \\
Chicken & $9.00 \pm 1.12$ & $5.54 \pm 1.46$ & 0.05 & $*$ \\
Duck & $2.20 \pm 1.13$ & $5.00 \pm 1.48$ & 0.13 & $\mathrm{NS}$ \\
Farmer (\%) & & & & \\
Native cattle & $91.25 \pm 0.03$ & $99.13 \pm 0.05$ & 0.05 & $*$ \\
Crossbred cattle & $7.5 \pm 0.05$ & $1.0 \pm 0.05$ & 0.001 & $* *$ \\
Buffalo & $0.5 \pm 0.08$ & $0.5 \pm 0.09$ & 0.90 & $\mathrm{NS}$ \\
Goat & $38.75 \pm 0.27$ & $40.25 \pm 0.27$ & 0.50 & $\mathrm{NS}$ \\
Sheep & $2.5 \pm 0.06$ & $2.75 \pm 0.06$ & 0.60 & $\mathrm{NS}$ \\
Chicken & $70.00 \pm 0.27$ & $69.00 \pm 0.27$ & 0.50 & NS \\
Duck & $36.00 \pm 1.13$ & $60.00 \pm 1.48$ & 0.01 & $* *$ \\
Livestock rearing (\%) & & & & \\
Tethering & $10.00 \pm 0.51$ & $87.5 \pm 0.50$ & 0.01 & $* *$ \\
Extensive & $63.75 \pm 0.05$ & $10.00 \pm 0.05$ & 0.01 & $* *$ \\
Semi-extensive & $36.25 \pm 0.05$ & $90.00 \pm 0.05$ & 0.01 & $* *$ \\
Livestock keeping experience (Years) & $18.96 \pm 1.30$ & $14.51 \pm 1.30$ & 0.01 & $*$ \\
\hline
\end{tabular}

** Significant at $1 \%$ level $(\mathrm{P}<0.01),{ }^{*}$ Significant at $5 \%$ level $(\mathrm{P}<0.05), \mathrm{NS}=$ Non significant $(\mathrm{P}>0.05)$ 
inadequate feed and fodder along with poor genetic make-up and incidence of diseases. In this connection previous studies showed that by providing training \& input supplies the beneficiary households made a substantial progress in livelihood (Alam, 1997) in Banladesh. A Community Livestock Development Project was taken by Nepal to reduce poverty and up-gradation of
Community Livestock Development Project, publication stock No. ARM125064-2 October 2012). G.

\section{Household consumption scenario}

The comparative scenario of consumption of different food items in studied areas are shown in Table 7. The per capita daily food

Table 6. Productive and Reproductive parameters of cattle at community farmers

\begin{tabular}{lccrr}
\hline Parameters & \multicolumn{2}{c}{ Location } & P-value & Sig. level \\
\cline { 2 - 3 } & Jaintapur & Balaganj & & \\
\hline Milking cow (Number/farmer) & $1.45 \pm 0.95$ & $1.65 \pm 0.95$ & 0.54 & NS \\
Milk prod. (lac./Animal/day) & $1.40 \pm 0.4$ & $1.6 \pm 0.34$ & 0.72 & NS \\
Lactation period (day) & $183.26 \pm 3.49$ & $178 \pm 3.49$ & 0.34 & NS \\
Milk production./Lac. & $256.56 \pm 0.3$ & $284.8 \pm 0.4$ & 0.21 & NS \\
Calf production/year & $1.20 \pm 0.25$ & $1.15 \pm 0.25$ & 0.89 & NS \\
Calf weight (kg) & $12.60 \pm 0.76$ & $12.45 \pm 0.76$ & 0.89 & NS \\
Artificial Insemination (\%) & $24.65 \pm 2.41$ & $28.77 \pm 2.14$ & 0.23 & NS \\
Repeat AI (\%) & $35.00 \pm 0.07$ & $33.00 \pm 0.27$ & 1.00 & NS \\
Litter size & $1.20 \pm 0.25$ & $1.15 \pm 0.25$ & 0.89 & NS \\
\hline
\end{tabular}

$\mathrm{NS}=$ Non significant $(\mathrm{P}>0.05)$

livelihood through development of livestock community resulting increased cow milk production by $140 \%$ and that of buffalo by $57 \%$, compared with the target of $50 \%$. Goat off-take increased by $28 \%$ in the intensive livestock production districts, against the target of $30 \%$. (Asian Development Bank; intake in both locations did not differed significant $(\mathrm{P}>0.05)$ but a good amount of food items were consumed by the community farmers in both locations.

All of the farm families purchased more than $80 \%$ of their consumed foods and rest of amount meet up to their own production.

Table 7. Daily food consumption of community farmers

\begin{tabular}{lcccc}
\hline \multirow{2}{*}{ Food items } & \multicolumn{2}{c}{ Location } & P-value & \multirow{2}{*}{ Sig. level } \\
\cline { 2 - 3 } & Jaintapur & Balaganj & & \\
\hline Rice (g/person) & $100.41 \pm 29.45$ & $77.26 \pm 33.10$ & 0.60 & NS \\
Flour (g/person) & $71.07 \pm 22.94$ & $42.11 \pm 23.81$ & 0.38 & NS \\
Milk (g/person) & $126.33 \pm 35.77$ & $125.88 \pm 35.77$ & 0.99 & NS \\
Meat (g/person) & $119.32 \pm 37.15$ & $134.73 \pm 36.43$ & 0.76 & NS \\
Fish (g/person) & $102.46 \pm 34.43$ & $110.46 \pm 34.43$ & 0.87 & NS \\
Pulse (g/person) & $76.69 \pm 20.77$ & $19.12 \pm 21.62$ & 0.06 & NS \\
Egg (g/week) & $74.30 \pm 27.23$ & $92.48 \pm 27.77$ & 0.64 & NS \\
Veg (g/person) & $63.91 \pm 30.38$ & $112.57 \pm 29.19$ & 0.25 & NS \\
\hline
\end{tabular}

$\mathrm{NS}=$ Non significant $(\mathrm{P}>0.05)$, Veg- Vegetables 


\section{Constraints}

The summary of the farmer's responses on the constraints faced regarding in rearing livestock and poultry in study areas shown in Table 8. Lack of feed resources and technology intervention and treatment against disease outbreak were the main constraints and found non significantly differed among the two locations. covering suitable livestock and poultry technology intervention, training for awareness and developed monitoring and providing technical support in selected areas leads to icrease farmer's income and reducing poverty improve livelihood accordingly. All these constraints should be addressed by the extension agent's researchers and policy makers to ensure sustainability in the production system.

Table 8. Acute problems of the community farmers

\begin{tabular}{lllll}
\hline Study Area & \multicolumn{3}{c}{ Acute Problems } \\
\cline { 2 - 5 } & Feed & Treatment & Lack of technology & Training \\
\hline Jointapur & $1.00 \pm 0.09$ & $1.00 \pm 0.07$ & $1.00 \pm 0.08$ & $0.46 \pm 0.08$ \\
Balagonj & $1.00 \pm 0.05$ & $1.00 \pm 0.04$ & $1.00 \pm 0.05$ & $0.47 \pm 0.07$ \\
P value & 1.00 & 0.90 & 0.90 & 0.90 \\
\hline Sig
\end{tabular}

\begin{tabular}{llll}
\hline Sig.level NS & NS & NS & NS \\
\hline
\end{tabular}

*** Significant at $0.1 \%$ level $(\mathrm{P}<0.001)$

\section{Reference}

A limitation of training programme or awareness build up activities was also an acute problem in study areas.

\section{Conclusion}

The production performance of livestock species was found poor in the studied area due to inadequate feed and fodder supply poor genetic make-up lack of awareness irrespective of disease, good feeding and management practices in their farming system. Using trained manpower, land and feed resources properly with good practices adopting modern BLRI technologies could be a options to overcome this situation. The results of previous study indicated that positive response to technological interventions in regard to reduced mortality and increased productivity that means $10-59 \%$ in Belkuchi and $6-30 \%$ in Naichongchari. So, If we take proper measures to solve the observed problem under studied areas through technological intervention at farmers community level that will be activate to minimized and improved the overall farming situation as a whole. So, a sustainable community need to be developed
Asian Development Bank 2012. Community Livestock Development Project. Publication Stock No. ARM 125064-2

Alam, J. 1997. Impact of smallholder livestock development project in some selected areas of rural Bangladesh. Livestock for Rural Development, 9(3).

BBS. 2017. Statistical Yearbook of Bangladesh, Bangladesh Bureau of Statistics, Statistics Division, Ministry of Planning, Government of the People's Republic of Bangladesh, Dhaka.

Ndlovu, L. 2010. Food, nutrition and health. In: Swanepoel, F.J.C., Stroebel, A. \&Moyo, S. (Eds) The role of livestock in developing communities: Enhancing multifunctionality. CTA, Wageningen, The Netherlands.

Pell, A.N., Stroebel, A. and Kristjanson, P. 2010. Livestock development projects that make a difference: What works, what doesn't and why. In: Swanepoel, F.J.C., Stroebel, A.\&Moyo, S. (Eds). The role of livestock in developing communities: Enhancing multifunctionality. CTA, Wageningen, The Netherlands.

Tembo, G., Chapoto, A. Jayne, and T. Weber. M. 2009. "Fostering Agricultural Market Development in Zambia." Food Security Research Project Working Paper No. 40, FSRP, LusakaUddin, M. 